\title{
Comparing Ginsenoside Production in Leaves and Roots of Wild American Ginseng (Panax quinquefolius)
}

\author{
James Matthew Searels, Karissa D. Keen, Jonathan L. Horton*, H. David Clarke, Jennifer Rhode Ward
}

Biology Department, University of North Carolina at Asheville, Asheville, USA.

Email: jhorton@unca.edu

Received April 10 $0^{\text {th }}, 2013$; revised May 10 ${ }^{\text {th }}, 2013$; accepted June $1^{\text {st }}, 2013$

Copyright (C) 2013 James Matthew Searels et al. This is an open access article distributed under the Creative Commons Attribution License, which permits unrestricted use, distribution, and reproduction in any medium, provided the original work is properly cited.

\begin{abstract}
American ginseng, Panax quinquefolius L., is an herbaceous perennial species that is destructively harvested for its bioactive compounds called ginsenosides. The demand for this herb fosters illegal poaching and over-harvesting that reduces genetic variability and population viability. Five wild populations in western North Carolina were studied to better understand the production of ginsenosides in leaf and root tissues. Total ginsenoside concentration was significantly higher in leaves than roots, though total yield was higher in roots due to greater root biomass. However, some ginsensosides ( $\mathrm{Rb} 2, \mathrm{Rd}$ and $\mathrm{Re}$ ) had higher or more consistent yields in leaves than roots, so might be developed into a sustainable source of these medicinally-active compounds. Additionally, we identified regional root chemotypes that differed in the production of the ginsenosides $\operatorname{Rg} 1$ and $\mathrm{Re}$ and could be developed into regional cultivars depending on the desired panel of ginsenosides.
\end{abstract}

Keywords: American Ginseng; Chemotypes; Ginsenosides; HPLC; Medicinal Plants; Panax quinquefolius

\section{Introduction}

American ginseng (Panax quinquefolius L.) produces secondary metabolites called ginsenosides. These are saponins of the steroidal family, which act as anti-microbial [1] and anti-herbivory agents [2]. Of the greater than 30 different ginsenoside compounds described [3], several have been documented as having anti-inflammatory and anti-diabetic [4], anti-tumorigenic [5] or chemopreventive properties within the human body [6]. They are also thought to have adaptogen or tonic activeties, increasing the body's ability to endure stress via immunostimulatory and endocrinological effects $[7,8]$.

Dried American ginseng roots are prized on Asian markets for their calming and nourishing medicinal properties $[9,10]$. These properties contrast those of Asian ginseng (Panax ginseng C.A Meyer) whose roots have been used in Asia for over 500 years, to improve stamina, concentration, healing processes, stress resistance, vigilance and work efficiency [11]. With increased domestic and European use of American ginseng for dietary health supplements and food additives [12], American ginseng sales have increased and American ginseng is one of the ten most valuable herbal dietary supplements in the

"Corresponding author.
United States [13].

American ginseng is a non-clonal, slow growing, perennial herb with late successional characteristics [14], including seeds with an extended dormancy period of 18 - 22 months [7,15]. Thus, destructive harvesting has negative impacts on population viability [16]. To meet increasing demand, wild plants are being overharvested throughout North America [12], leading to declines in population size and fitness [17-19]. These pressures could eventually render wild harvests ecologically and economically unsustainable.

In Asian markets ginseng roots' values are typically determined by qualitative factors, such as, root shape, size, and color [20]. However, there has been much interest in understanding the factors affecting ginsenoside production in roots, and most research has focused on young ( $\leq 4$ years) cultivated roots. Many ginsenoside concentrations have been shown to be higher in leaves than in roots [2125] except $\mathrm{Rb} 1$ [26]. While above-ground tissues are not currently valued in traditional Asian markets [4], they may be developed as a sustainable source to meet the growing demand for phytomedicines and dietary supplements in western markets $[27,28]$. Root biomass is much greater than above-ground biomass (this study), but higher overall ginsenoside concentrations in the above- 
ground tissues might allow for the development of a long-term sustainable resource. Biomass, stem height, number of leaves and leaf area all increase with plant age $[18,29]$, so repeated non-destructive harvesting of aboveground tissues could result in higher overall yields of some ginsenosides.

In this study, we examined the ginsenoside composition of leaf and root tissue in plants from five wild populations of American ginseng in western North Carolina. This study is part of a larger project to help develop cultivation protocols and cultivars to maximize the production of ginsenosides in both roots and leaves. These efforts will help help foster more sustainable ginsensoside production for the growing market.

\section{Materials and Methods}

In summer 2011, we identified and gathered morphological data on every American ginseng plant found in five Western North Carolina populations $(\mathrm{MC}=$ Macon County, $\mathrm{HC}=$ Haywood County, BC1, BC2 and BC3 in Buncombe County). Site information is purposefully vague due to the pressures of illegal poaching on this species. All individuals were numbered, tagged below the leaf litter, and mapped using a laser range finder and mapping software (True Pulse 360, Laser Technology Inc. Centennial, $\mathrm{CO}$ ) for ease of future relocation. From each population ten three-leaf reproductive individuals were randomly selected $(\mathrm{N}=50$ total). Environmental and physiological characteristics were measured for these individuals (data not shown) and their root and leaf ginsenosides were quantified. As a result of illegal poaching among our sites, only 30 roots were harvested at the end of the growing season. Additionally, shoots of three individuals were absent at the time of harvest due to herbivory, so only 27 shoots were harvested. Total root wet biomass was measured, then a subsample was taken from the terminal end of each root for ginsenoside analysis. The remaining root tissue was replanted. Dry biomass of leaves, and wet and dry mass of root subsamples were measured using an analytical balance. Total root dry biomass was estimated by multiplying the wet root biomass of the total root by the wet root/dry root ratio of the subsamples. Each plant was aged by counting annual rhizome scars [29] yielding an age range of 6 to 26 years (Table 1). During processing, four root and two leaf samples were destroyed, yielding a total of 26 roots and 25 leaves for ginsenoside analysis.

High Performance Liquid Chromatography (HPLC) (PerkinElmer Series 200, Shelton, CT) methods developed for American ginseng $[21,30]$ were performed using a 3 $\mu \mathrm{m}, 150 \times 3.0 \mathrm{~mm}, \mathrm{C} 18$ column (Thermo Scientific, West Palm Beach, FL) to analyze ginsenoside content and concentration of roots and leaves. Tissues were separated, dried at $35^{\circ} \mathrm{C}$ for 24 hours [20] and ground with a Wiley mill to pass a 40 mesh screen. We extracted ginsenosides from the dried samples with a 50:50 ethanol:water solution and air dried under vacuum at ambient temperatures for approximately 96 hours. HPLC purified samples of the six most abundant ginsenosides: $\mathrm{Rb} 1, \mathrm{Rb} 2$, $\mathrm{Rc}, \mathrm{Rd}, \mathrm{Re}$ and Rg1 (Indofine Chemical Co., Inc., Hillsborough, NJ) were purchased to produce stock standards (between $587.6 \mu \mathrm{g} / \mathrm{mL}$ and $983.2 \mu \mathrm{g} / \mathrm{mL}$ ) re-suspended in a 20:20:60 HPLC grade ethanol:acetonitril:water solution [30]. The injection volumes were modified to range between $1 \mu \mathrm{L}$ to $50 \mu \mathrm{L}$ in order to linearly interpolate a standard curve within an expected range. Additionally, all leaf samples were diluted by a factor of five to achieve appropriate separation among chromatograph peaks.

We were unable to statistically compare concentrations across sites because illegal poaching reduced the number of samples at two sites $(\mathrm{BC} 1=1$ and $\mathrm{BC} 2=2)$. Data were pooled across sites to increase the statistical power in comparisons of root and leaf ginsenoside concentrations. Concentration and yield (concentration * biomass) of ginsenosides were analyzed between leaf and root tissues using nonparametric analysis of variance (Kruskal-Wallis Test) because these data were not normally distributed. Ginsenoside concentrations and biomass were related to plant age and tissue biomass with Pearson correlation analysis. All analyses were performed using SAS (Statistical Analysis Software Version 9.2, Cary, NC).

\section{Results and Discussion}

Total ginsenoside of concentration plants pooled across all sites was significantly higher $(p=0.007)$ in leaves compared to roots, as were the concentrations of $\mathrm{Rb} 2$ and $\operatorname{Rd}(\mathrm{p}<0.0001$ for both; Table 1). These tissue patterns were also observed in commercially cultivated plants from Wisconsin $(23,24)$ and British Columbia $(21)$. The concentration of ginsenosides $\mathrm{Rg} 1$ and $\mathrm{Rb} 1$ were significantly $(p<0.0001)$ higher in roots than leaves. In leaves, the most abundant ginsenoside was Rb2, while the most abundant root ginsenoside was Rb1. Rd was found in high concentrations in both leaves and roots while, Re was found in relatively high concentrations in all leaves, but was only found in nine roots from two populations (Table 1). Total ginsenoside yield (concentration * biomass) was significantly $(p=0.035)$ higher in roots than leaves due to significantly $(\mathrm{p}<0.0001)$ greater root biomass (Table 2). Yield of $\operatorname{Rg} 1$ (p < 0.0001), Rb1 (p < $0.0001)$ and $R c(p=0.010)$ were significantly higher in roots than leaves, as was $\operatorname{Re}(p<0.0001)$ in the nine roots where it was found, while yield of Rb2 $(p<0.0001)$ and $\operatorname{Rd}(\mathrm{p}=0.0005)$ were significantly higher in leaves than roots (Table 2). 


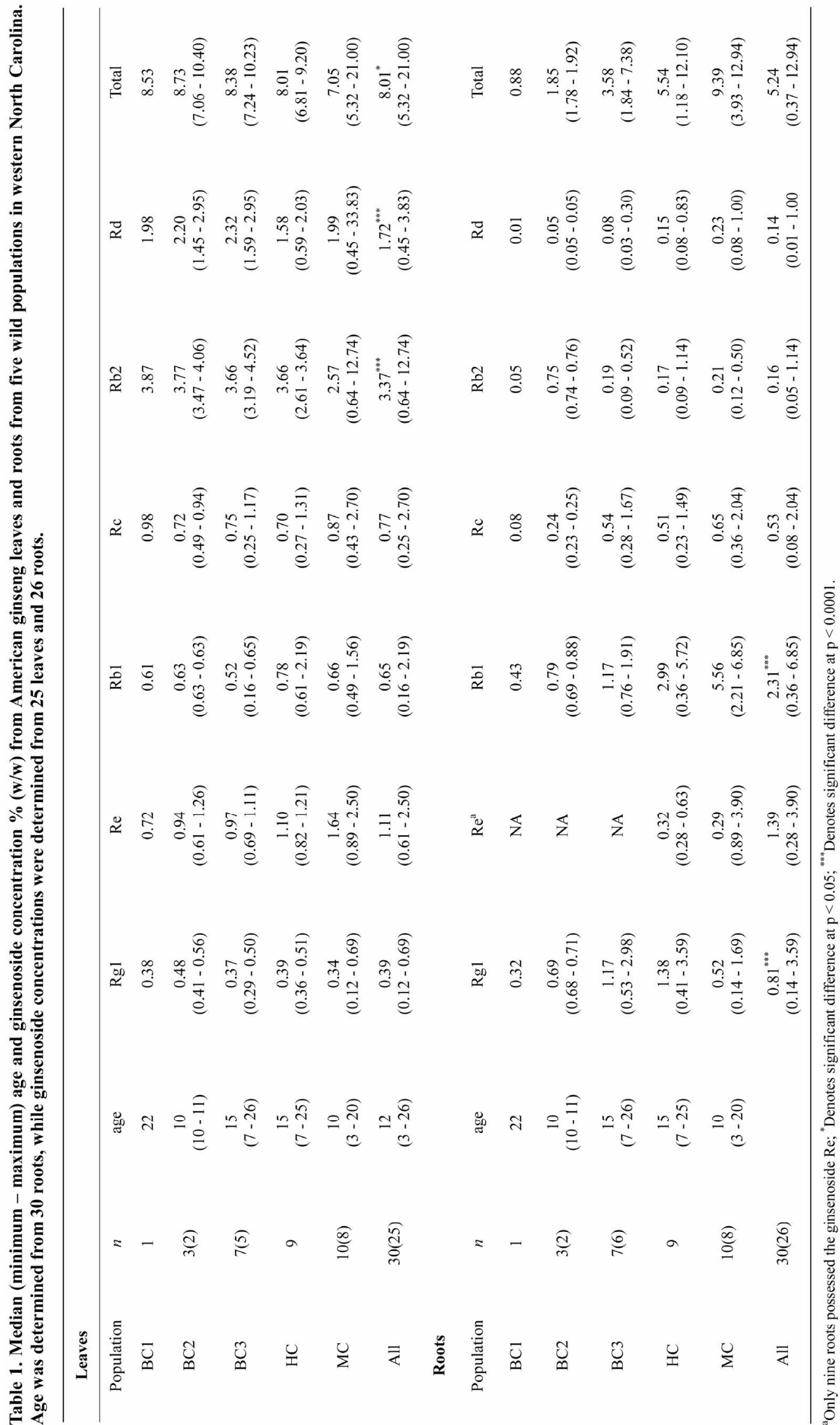




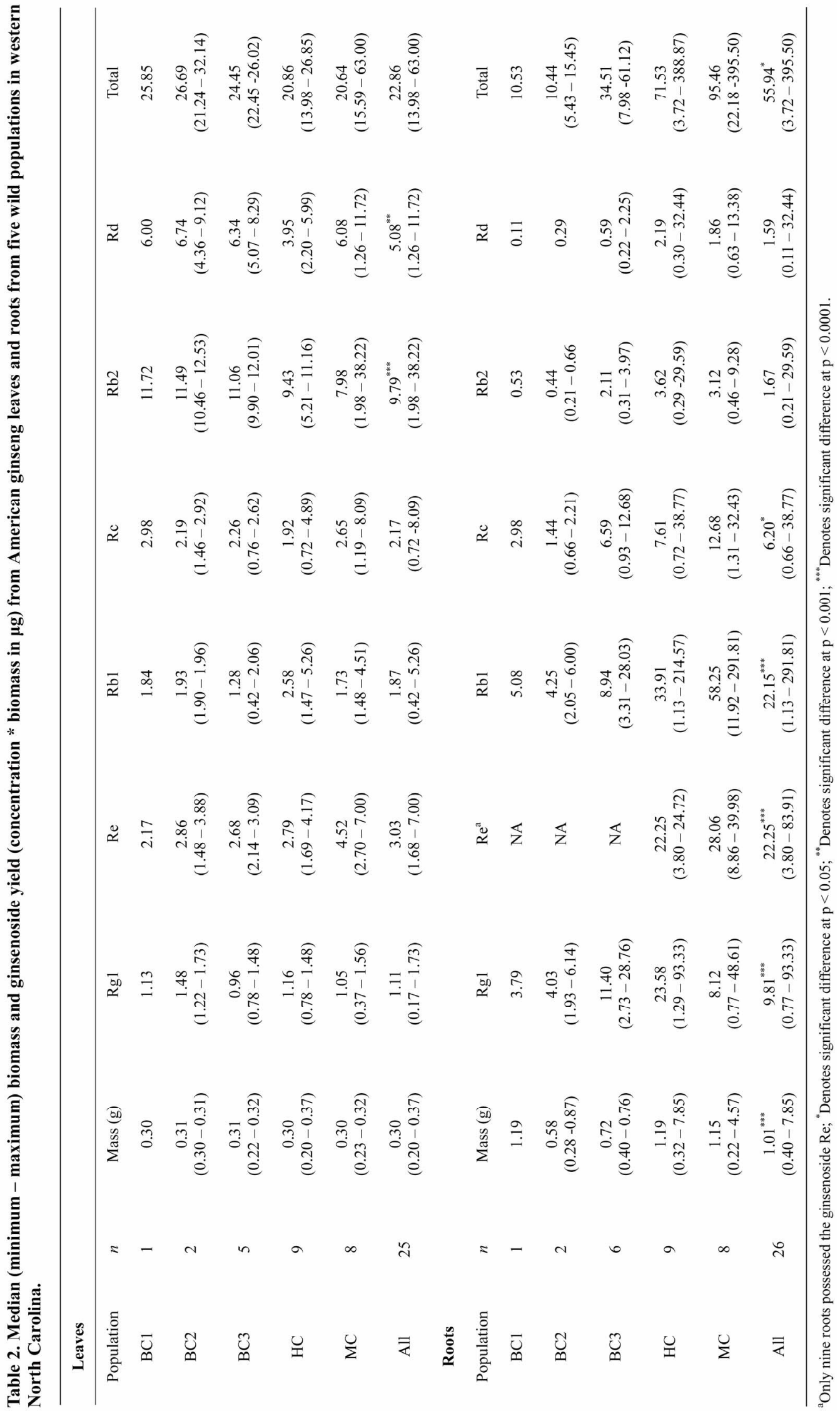


No significant relationship was found between plant age or root biomass and root ginsenoside concentration (Table 3) in our study, although total root ginsenoside concentration (driven by $\mathrm{Rb} 1$ and $\mathrm{Re}$ ) were shown to increase with age in cultivated American ginseng in Ontario, Canada [31]. In leaves, Re concentration, but no other ginsenosides, decreased significantly $(p=0.046)$ with plant age, while $\mathrm{Rg} 1$ concentration decreased with increasing leaf biomass (Table 3). Leaf number and leaf area are known to increase with plant age [18,29], however, we did not observe this pattern, likely because we chose plants of similar size and reproductive status before ageing them. Ginsenoside yields in leaves were not related to age or biomass, but yields in most ginsenosides (except Re) increased with increasing root biomass (Table 4).

Table 3. Correlation coefficients (and p-values) between ginsenoside concentration $(\mathrm{w} / \mathrm{w}) \%$ and age and biomass. Bolded values denote significant relationships.

\begin{tabular}{|c|c|c|c|c|c|c|c|}
\hline leaf & Rg1 & $\mathrm{Re}$ & $\mathrm{Rb} 1$ & $\mathrm{Rc}$ & $\mathrm{Rb} 2$ & $\mathrm{Rd}$ & Total \\
\hline Age & $\begin{array}{c}-0.274 \\
0.185\end{array}$ & $\begin{array}{c}-0.403 \\
0.045\end{array}$ & $\begin{array}{l}0.120 \\
0.568\end{array}$ & $\begin{array}{c}-0.204 \\
0.328\end{array}$ & $\begin{array}{l}0.125 \\
0.552\end{array}$ & $\begin{array}{l}0.202 \\
0.332\end{array}$ & $\begin{array}{l}0.055 \\
0.795\end{array}$ \\
\hline Biomass & $\begin{array}{c}-0.402 \\
0.047\end{array}$ & $\begin{array}{c}-0.161 \\
0.442\end{array}$ & $\begin{array}{c}-0.125 \\
0.552\end{array}$ & $\begin{array}{l}0.116 \\
0.582\end{array}$ & $\begin{array}{l}0.066 \\
0.755\end{array}$ & $\begin{array}{c}-0.100 \\
0.634\end{array}$ & $\begin{array}{c}-0.019 \\
0.927\end{array}$ \\
\hline Root & $\operatorname{Rg} 1$ & $\mathrm{Re}$ & $\mathrm{Rb} 1$ & $\mathrm{Rc}$ & $\mathrm{Rb} 2$ & $\mathrm{Rd}$ & Total \\
\hline Age & $\begin{array}{l}0.162 \\
0.429\end{array}$ & $\begin{array}{l}0.113 \\
0.773\end{array}$ & $\begin{array}{c}-0.137 \\
0.504\end{array}$ & $\begin{array}{l}0.144 \\
0.483\end{array}$ & $\begin{array}{l}0.156 \\
0.446\end{array}$ & $\begin{array}{c}-0.097 \\
0.636\end{array}$ & $\begin{array}{c}-0.043 \\
0.836\end{array}$ \\
\hline Biomass & $\begin{array}{l}0.109 \\
0.598\end{array}$ & $\begin{array}{c}-0.437 \\
0.240\end{array}$ & $\begin{array}{l}0.351 \\
0.079\end{array}$ & $\begin{array}{l}0.040 \\
0.845\end{array}$ & $\begin{array}{l}0.060 \\
0.769\end{array}$ & $\begin{array}{l}0.280 \\
0.167\end{array}$ & $\begin{array}{l}0.258 \\
0.203\end{array}$ \\
\hline
\end{tabular}

Table 4. Correlation coefficients (and p-values) between ginsenoside yield $(\mu \mathrm{g})$ and age and biomass. Bolded values denote significant relationships.

\begin{tabular}{|c|c|c|c|c|c|c|c|}
\hline Leaf & $\operatorname{Rg} 1$ & $\mathrm{Re}$ & $\mathrm{Rb} 1$ & $\mathrm{Rc}$ & $\mathrm{Rb} 2$ & $\mathrm{Rd}$ & Total \\
\hline Age & $\begin{array}{c}-0.217 \\
0.298\end{array}$ & $\begin{array}{c}-0.344 \\
0.092\end{array}$ & $\begin{array}{l}0.137 \\
0.513\end{array}$ & $\begin{array}{c}-0.183 \\
0.382\end{array}$ & $\begin{array}{l}0.130 \\
0.535\end{array}$ & $\begin{array}{l}0.232 \\
0.264\end{array}$ & $\begin{array}{l}0.083 \\
0.694\end{array}$ \\
\hline Biomass & $\begin{array}{l}0.102 \\
0.627\end{array}$ & $\begin{array}{l}0.184 \\
0.378\end{array}$ & $\begin{array}{l}0.130 \\
0.536\end{array}$ & $\begin{array}{l}0.327 \\
0.110\end{array}$ & $\begin{array}{l}0.241 \\
0.246\end{array}$ & $\begin{array}{l}0.167 \\
0.426\end{array}$ & $\begin{array}{l}0.300 \\
0.146\end{array}$ \\
\hline Root & $\operatorname{Rg} 1$ & $\mathrm{Re}$ & $\mathrm{Rb} 1$ & $\mathrm{Rc}$ & $\mathrm{Rb} 2$ & $\mathrm{Rd}$ & Total \\
\hline Age & $\begin{array}{l}0.219 \\
0.282\end{array}$ & $\begin{array}{l}0.460 \\
0.212\end{array}$ & $\begin{array}{l}0.085 \\
0.679\end{array}$ & $\begin{array}{l}0.202 \\
0.324\end{array}$ & $\begin{array}{l}0.183 \\
0.370\end{array}$ & $\begin{array}{l}0.092 \\
0.656\end{array}$ & $\begin{array}{l}0.142 \\
0.488\end{array}$ \\
\hline Biomass & $\begin{array}{c}0.739 \\
<0.001\end{array}$ & $\begin{array}{l}0.116 \\
0.767\end{array}$ & $\begin{array}{c}0.845 \\
<0.0001\end{array}$ & $\begin{array}{c}0.698 \\
<0.0001\end{array}$ & $\begin{array}{l}0.459 \\
0.018\end{array}$ & $\begin{array}{c}0.794 \\
<0.0001\end{array}$ & $\begin{array}{c}0.842 \\
<0.0001\end{array}$ \\
\hline
\end{tabular}

There have been reports of American ginseng chemotypes in North America populations that differ in the ratio of $\operatorname{Rg} 1: \operatorname{Re}$. Universally low $\operatorname{Rg} 1: \operatorname{Re}$ chemotypes were reported for wild and cultivated plants from the northern and Midwestern regions of North America [22,24]. Another study found low $\operatorname{Rg} 1: \operatorname{Re}$ chemotypes in cultivated plants grown from seed collected in Tennessee and Wisconsin, but high $\operatorname{Rg} 1: \operatorname{Re}$ chemotypes in cultivated and wild populations from Maryland [12], with some plants not producing detectable amounts of Re. In our study, we found Re in some, but not all, roots from two populations (HC and MC), and we found Re in roots of some, but not all, plants from the population $\mathrm{BC} 2$ in a previous survey. A new system for describing these chemotypes has been proposed $(\mathrm{Re} / \mathrm{Rg} 1)$ that recognizes the lack of production of Re and removes the problem of chemotype ratios with a denominator of zero (M. McIntosh pers. comm.). In this system roots are classified into the following chemotypes: $\operatorname{Rg}(\operatorname{Re} / \operatorname{Rg} 1<1.0)$, Int $(\operatorname{Re} / \operatorname{Rg} 1$ between 1 and 2$)$, and $\operatorname{Re}(\operatorname{Re} / \operatorname{Rg} 1>2)$. Using this classification, we found three of eight plants from $\mathrm{HC}$ to be the "Rg1" chemotype $(\operatorname{Re} / \operatorname{Rg} 1$ all $<0.35)$ and six of eight plants at MC to be the "Re" chemotype (Table 5; Figure 1). We might consider adding another chemotype classification of "no Re", which encompasses the majority of the plants in this study. Additionally, in 2010, we found Re in three out of ten roots from $\mathrm{BC} 2$, but have no leaf ginsenoside data on those plants.

Table 5 Individual Re and Rg1concentrations (w/w)\%, Re/ Rg1 ratios and chemotype of ginseng roots containing Re from three wild populations.

\begin{tabular}{cccccc}
\hline Population & Plant & Re & Rg1 & Re/Rg1 & Chemotype \\
\hline BC2 $^{*}$ & D & 3.54 & 0.55 & 0.64 & $\operatorname{Re}$ \\
BC2 $^{*}$ & W & 6.05 & 0.72 & 0.84 & $\operatorname{Re}$ \\
BC2 $^{*}$ & 38 & 6.30 & 0.76 & 0.83 & $\operatorname{Re}$ \\
HC & 385 & 0.32 & 1.99 & 0.16 & $\operatorname{Re}$ \\
HC & 409 & 0.63 & 2.06 & 0.31 & $\operatorname{Re}$ \\
HC & 412 & 0.28 & 8.18 & 0.35 & $\operatorname{Re}$ \\
MC & 522 & 1.39 & 0.44 & 3.16 & $\operatorname{Rg} 1$ \\
MC & 529 & 2.55 & 0.80 & 3.20 & $\operatorname{Rg} 1$ \\
MC & 528 & 3.11 & 0.53 & 5.84 & $\operatorname{Rg} 1$ \\
MC & 521 & 0.89 & 0.14 & 6.51 & $\operatorname{Rg} 1$ \\
MC & 526 & 3.90 & 0.51 & 7.70 & $\operatorname{Rg} 1$ \\
\hline
\end{tabular}

${ }^{*}$ Data from roots harvested in 2010. 
These plants would be classified as "Re", but had higher $\mathrm{Re} / \mathrm{Rg} 1$ ratios than $\mathrm{HC}$ plants $(\mathrm{Re} / \mathrm{Rg} 1$ between 0.6 and 0.9 ). Regional variations of ginsenoside content are thought to be predominately influenced by genetic rather than environmental factors [12]. A recent study of 157 populations throughout North America confirmed two main genotypes in ginseng's northern range separated by the Appalachian Mountains. However, the southern part of ginseng's range showed greater genetic variability, likely due to this region acting as a refugium during the last glaciation [32]. We found the ginsenoside Re in leaves of all populations but only in the roots of three populations (two in 2011 and one in 2010) at varying concentrations.

Because the individual concentrations of ginsenosides differ between leaves and roots, the harvest of aboveground tissues may provide a more reliable stock for individual ginsenosides. The ginsenosides $\mathrm{Rb} 2$ and $\mathrm{Rd}$ which were in higher concentrations and yields in leaves than roots, while Re was consistently found in leaves, but not was not found in all roots. Because leaves contain higher or more consistent concentrations of these three ginsenosides, they might be more reliably supplied by leaf tissue harvests than root harvests. Non-destructive harvest of above-ground tissues late in the growing season after seed production could help conserve ginseng populations by providing a sustainable source for these compounds without harvesting entire plants. While root biomass, and thus ginsenoside yield, might result in greater one time harvest yields, the continued harvest of above-ground tissues could supply a greater overall yield in the long term. However, growth of above-ground tissues is not necessarily linear through time. Generally, plants progress from 1-leaf to 2-leaf, 3-leaf and even 4-leaf [29], however, it is possible for size class to regress (e.g., 3-leaf to 2-leaf) or remain dormant throughout successive seasons due to environmental conditions or loss of tissue to herbivory [33]. Future studies should quantify the effect of harvesting above-ground tissues on the growth and progression of ginseng plants and populations.

As of 1994, the US Food and Drug Administration (FDA) classified ginseng as a dietary supplement under the Dietary Supplemental Health and Education Act (DSHEA). In 2007, the FDA issued the "Dietary Supplement Current Good Manufacturing Practices Final Rule" to go into effect in 2008 to ensure that dietary supplement products sold are processed in a consistent manner, meet quality control standards, and are properly labeled [34]. Labels are supposed to contain 1) name of the dietary supplement, 2) amount of the dietary supplement, 3) the nutrition labeling and, 4) the ingredient list. Ginsenosides are known to have different effects in the body and ginseng can be used to treat different ailments.
For example, $\mathrm{Rb} 2$ is known to act as a tumor inhibitor [35,36], while Rd [37] and Re [38] are used as antioxidants. Different chemotypes within and among American ginseng populations will require better determination and labeling of chemotypes in products marketed in the United States. Future studies should assay additional populations in the southern Appalachian region to determine the number and distribution of different chemotypes. Additionally, genetic analyses should be conducted to identify molecular markers associated with these chemotypes to assist in proper identification and labeling.

\section{Acknowledgements}

We would like to thank Dr. Jeffrey Wilcox for assisting with and providing equipment for HPLC analysis, Scott Arico and Joseph McKenna for help in the field and laboratory, and the University of North Carolina at Asheville's Undergraduate Research Program, the NC Botanical Garden Izard Scholarship, and UNCA's University Research Council for funding.

\section{REFERENCES}

[1] S. A. Suits, "American Ginseng (Panax quinquefolium L.), the 'Other' Ginseng," Economic Botany, Vol. 57, 2003, pp. 143-144.

[2] J. M. Augustin, V. Kuzina, S. B. Andersen and S. Bak, "Molecular Activites, Biosynthesis and Evolution of Triterpenoid Sapoinins," Phytochemistry, Vol. 72, No. 6, 2011, pp. 435-457. doi:10.1016/i.phytochem.2011.01.015

[3] W.W. Chuang, H.K. Wu, S.J. Sheu, S.H. Chiou, H.C. Chang and Y.P. Chen, "A comparative study on commercial samples of ginseng radix," Planta Medica, Vol. 61, No. 5, 1995, pp. 459-465. doi:10.1055/s-2006-958137

[4] X. Jing-Tian, S. R. Mehendale, A. Wang, A. H. Han, J. A. Wu, J. Osinski and C. S. Yuan, "American Ginseng Leaf: Ginsenoside Analysis and Hypoglycemic Activity," Pharmacology Research, Vol. 49, No. 2, 2004, pp. 113-117. doi:10.1016/j.phrs.2003.07.015

[5] Y. S. Keum, S. S. Han, K. S. Chun, K. K. Park, J. H. Park, S. K. Lee and Y. J. Surh, "Inhibitory Effects of the Ginsenoside $\mathrm{Rg}_{3}$ on Phorbol Ester-Induced Cyclooxygenase-2 Expression, NF- $\kappa \mathrm{B}$ Activation and Tumor Promotion," Mutation Research, Vol. 523-524, 2003, pp. 75-85. doi:10.1016/S0027-5107(02)00323-8

[6] L. W. Qi, C. Z. Wang and C. S. Yuan, "American Ginseng: Potential Structure-Function Relationship in Cancer Chemoprevention," Biochemical Pharmacology, Vol. 80, No. 7, 2010, pp. 947-954. doi:10.1016/i.bcp.2010.06.023

[7] C. C. Baskin and J. M. Baskin, "Seeds: Ecology, Biogeography, and Evolution of Dormancy and Germination," Academic Press, New York, 1998.

[8] T. Ligor, A. Ludwiczuk, T. Wolski and B. Buszewski, "Isolation and Determination of Ginsenosides in American Ginseng Leaves and Root Extracts by LC-MS," Ana- 
lytical and Bioanalalytical Chemistry, Vol. 383, No. 7-8, 2005 pp. 1098-1105. doi:10.1007/s00216-005-0120-8

[9] S. Dharmananda, "The Nature of Ginseng: Traditional Use, Modern Research, and the Question of Dosage," HerbalGram, Vol. 54, No. 1, 2002, pp. 34-51.

[10] E. P. Burkhart and M. G. Jacobson, "Transitioning from Wild Collection to Forest Cultivation of Indigenous Medicinal Forest Plants in Eastern North America Is Constrained by Lack of Profitability," Agroforestry Systems, Vol. 76, No. 2, 2008, pp. 427-453.

[11] E. Nocerino, M. Amato and A. A. Izzo, "The Aphrodisiac and Adaptogenic Properties of Ginseng," Fitoterapia, Vol. 71, No. 1, 2000, pp. S1-S5. doi:10.1016/S0367-326X(00)00170-2

[12] E. M. Schlag and M. S. McIntosh, "Ginsenoside Content and Variation among and within American Ginseng (Panax quinquefolius L.) Populations," Phytochemistry, Vol. 67, No. 14, 2006, pp. 1510-1519. doi:10.1016/j.phytochem.2006.05.028

[13] M. Blumenthal, A. Lindstrom, C. Ooyen and M. E. Lynch, "Herb Supplement Sales Increase 4.5\% in 2011," HerbalGram, Vol. 95, No. 1, 2012, pp. 60-64.

[14] M. A. Albrecht and B. C. McCarthy, "Seedling Establishment Shapes the Distribution of Shade-Adapted Forest Herbs across a Topographical Moisture Gradient," Journal of Ecology, Vol. 97, No. 5, 2009, pp. 1037-1049. doi:10.1111/j.1365-2745.2009.01527.x

[15] D. Charron and D. Gagnon, "The Demography of Northern Populations of Panax quinquefolium (American Ginseng)," Journal of Ecology, Vol. 79, No. 2, 1991, pp. 431-445. doi: $10.2307 / 2260724$

[16] P. Nantel, D. Gagnon and A. Nault, "Population Viability Analysis of American Ginseng and Wild Leek Harvested in Stochastic Environments," Conservation Biology, Vol. 10, No. 2, 1996, pp. 605-621. doi:10.1046/j.1523-1739.1996.10020608.x

[17] E. H. Mooney and J. B. McGraw, "Alteration of Selection Regime Resulting from Harvest of American Ginseng, Panax quinquefolius," Conservation Genetics, Vol. 8, No. 1, 2007, pp. 57-67. doi:10.1007/s10592-006-9148-3

[18] E. H. Mooney and J. B. McGraw, "Relationship between Age, Size and Reproduction in Populations of American Ginseng, Panax quinquefolius (Araliaceae), across a Range of Harvest Pressures," Ecoscience, Vol. 16, No. 1, 2009, pp. 84-94. doi:10:10.2980/16-1-3168

[19] J. M. Cruse-Sanders, J. L. Hamrick and J. A. Ahumada, "Consequences for Harvesting for Genetic Diversity in American Ginseng (Panax quinquefolius L.): A Simulation Study," Biodiversity Conservation, Vol. 14, No. 2, 2005, pp. 493-504. doi:10.1007/s10531-004-7308-7

[20] V. J. Davidson, X. Li and R. B. Brown, "Forced-Air Drying of Ginseng Root: 1. Effects of Air Temperature on Quality," Journal of Food Engineering, Vol. 63, No. 4, 2004, pp. 361-367. doi:10.1016/j.jfoodeng.2003.08.014

[21] T. S. C. Li, G. Mazza, A. C. Cottrell and L. Gao, "Ginsenosides in Roots and Leaves of American Ginseng," Journal of Agricultural and Food Chemistry, Vol. 44, No. 3, 1996, pp. 717-720. doi:10.1021/jf950309f
[22] V. A. Assinewe, B. R. Baum, D. Gagnon and J. T. Arnason, "Phytochemistry of Wild Populations of Panax quinquefolius L. (North American Ginseng)," Journal of Agricultural and Food Chemistry, Vol. 51, No. 16, 2003, pp. 4549-4553. doi:10.1021/jf030042h

[23] J.-T. Xie, S. R. Mehendale, A. Wang, A. H. Han, J. A. Wu, J. Osinki and C.-S. Yuan, "American Ginseng Leaf: Ginsenoside Analysis and Hypoglycemic Activity," Pharmacological Research, Vol. 49, No. 2, 2004, pp. 113-117. doi:10.1016/i.phrs.2003.07.015

[24] C.-Z. Wang, J. A. Wu, E. McEntee and C.-S. Yuan, "Saponins Composition in American Ginseng Leaf and Berry Assayed by High-Performance Liquid Chromatography," Journal of Agricultural and Food Chemistry, Vol. 54, No. 6, 2006, pp. 2261-2266. doi:10.1021/jf052993w

[25] C. L. Qu, Y. P. Bai and X. Q. Jin, "Study on Ginsenosides in Different Parts and Ages of Panax quinquefolius L.," Food Chemistry, Vol. 115, No. 1, 2009, pp. 340-346. doi:10.1016/j.foodchem.2008.11.079

[26] T. Ligor, A. Ludwiczuk, T. Wolski and B. Buszewski, "Isolation and Determination of Ginsenosides from American Ginseng Leaves and Root Extracts by LC-MS," Analytical and Bioanalytical Chemistry, Vol. 383, No. 7-8, 2005, pp. 1098-1105. doi:10.1007/s00216-005-0120-8

[27] D. P. Briskin, "Medicinal Plants and Phytomedicines," Plant Physiology, Vol. 124, No. 2, 2000, pp. 507-514. doi:10.1104/pp.124.2.507

[28] A. N. Starrat, J. G. Hendel and R. D. Reeleder, "Leaves of North American Ginseng, Panax quinquefolius L.: A Renewable Source of Certain Ginsenosides," Canadian Journal of Plant Science, Vol. 81, No. 1, 2006, pp. 65-67. doi:10.4141/P00-045

[29] R. C. Anderson, J. S. Fralish, J. E. Armstrong and P. K. Benjamin, "The Ecology and Biology of Panax quinquefolium L. (Araliaceae) in Illinois," American Midland Naturalist, Vol. 129, No. 2, 1993, pp. 357-372. doi: $10.2307 / 2426517$

[30] W. A. Court, J. G. Hendel and J. Elmi, "Reversed-Phase High-Performance Liquid Chromatographic Determination of Ginsenosides of Panax quinquefolium," Journal of Chromatography A, Vol. 755, No. 1, 1996, pp. 11-17. doi:10.1016/S0021-9673(96)00580-8

[31] W. A. Court, L. B. Reynolds and J. G. Hendel, "Influence of Root Age on the Concentration of Ginsenosides of American Ginseng (Panax quinquefolium)," Canadian Journal of Plant Science, Vol. 76, No. 4, 1996b, pp. 853855. doi: $10.4141 /$ cips $96-144$

[32] C. M. Lockstadt, E. B. Gonzales and J. Young, "Abstract: Reconstructing the Phylogeny of American Ginseng ( $\mathrm{Pa}$ nax quinquefolius, Araliaceae)," Southeastern Naturalist, Vol. 59, 2012, p. 241.

[33] S. J. Farrington, R. Muzika, D. Drees and T. M. Knight, "Ginseng Harvesting and Deer Herbivory," Conservation Biology, Vol. 23, No. 3, 2008, pp. 719-728. doi:10.1111/j.1523-1739.2008.01136.x

[34] US Food and Drug Administration, 2012. http://www.fda.gov/Food/DietarySupplements/Guidance 
ComplianceRegulatoryInformation/RegulationsLaws/ucm110858.htm

[35] J. Fujimoto, H. Sakaguchi, H. Tayaki, S. Khatun and T. Tamaya, "Inhibitory Effect of Ginsenoside-RB2 on Invasiveness of Uterine Endometrial Cancer Cells to the Basement Membrane," European Journal of Gynaecological Oncology, Vol. 222, 2001, pp. 339-341.

[36] M. Mochizuki, Y. C. Yoo, K. Matsuzawa, K. Sato, I. Saiki, S. Tono-oka, K. Samukawa and I. Azuma, "Inhibitory Effect of Tumor Metastasis in Mice by Saponis, Ginsenoside-Rb2, 20(R)- and 20(S)-Ginsenoside-Rg3, of Red Ginseng," Biological and Pharmaceutical Bulletin, Vol. 18, 1995, pp. 1197-1202.
[37] T. Yokozawa, A. Satoh and E. J. Cho, "Ginseonside-Rd Attenuates Oxidative Damage Related to Aging in Senescence-Acceleration Mice," Journal of Pharmacy and Pharmacology, Vol. 56, No. 1, 2004, pp. 107-113. doi: $10.1211 / 0022357022449$

[38] W. C. S. Cho, W.-S. Chung, S. K. Lee, A. W. N. Leung, C. H. K. Cheng and K. K. M. Yue, "Ginseoside, Re of Panax ginseng Possesses Significant Antioxidant and Antihyperlipidemic Efficacies in Streptozotocin-Induced Diabetic Rats," European Journal of Pharmacology, Vol. 550, No. 1-3, 2006, pp. 173-179. doi:10.1016/j.ejphar.2006.08.056 